\title{
PHYSICO-CHEMICAL CHARACTERISTICS OF GROUNDWATER AROUND SINGRAULI COALFIELD AREAS, SINGRAULI DISTRICT OF MADHYA PRADESH (INDIA)
}

\author{
Ashwani Kumar Sonkar*and Aarif Jamal \\ Department of Mining Engineering, \\ Indian Institute of Technology (Banaras Hindu University), Varanasi-221005, India \\ *E-mail : ashwanijack@gmail.com
}

\begin{abstract}
Groundwater is contaminated around Singrauli coalfield area due to mining and industrial activities. The major cause of the contamination of ground water may be due to improper disposal of industrial waste. The aim of the present study was to assess the groundwater quality and also to have a statistical analysis of physicochemical parameters of groundwater around Singrauli coalfield region, Singrauli District of Madhya Pradesh (India).Eight groundwater samples were collected from the hand pump \& Dug-wells located around Singrauli coalfields area during pre-monsoons and post monsoons seasons in the year 2018and analyzed for physicochemical parameters such aspH, TDS, EC, DO, Fluoride, Chlorides, Nitrate, Sulphate, Lithium, Sodium, Potassium, Magnesium and Calcium.A systematic calculation of the correlation coefficient has also been carried out between different analyzed parameters.
\end{abstract}

Keywords: Physicochemical Parameters, Correlation Co-efficient, Groundwater, Coalmines.

(C) RASĀYAN. All rights reserved

\section{INTRODUCTION}

Groundwater is one of the most significant water resources in India for drinking, domestic, irrigation and industrial uses. According to the WHO organization, about $80 \%$ of all the diseases in human beings are caused by water ${ }^{1}$. About $80 \%$ of the rural domestic water supply and $45 \%$ of the irrigation water supply in the country are met by the groundwater resources ${ }^{3-4}$.Availability and occurrence of groundwater depends on the rainfall and recharge conditions of the area. Groundwater quality comprises the chemical, physical and biological characteristics of groundwater. The suitability of groundwater for various uses majorly depends on the quality of groundwater ${ }^{2}$.Mining activity significantly affects the local environmental system in various ways, including land subsidence, lowering the groundwater table, Ground and Surface water quality and mine gas emissions. Open cast coal mining activities disturb the hydro-geological system and result in physical, chemical and environmental changes often resulting in pollution of both surface and groundwater ${ }^{5}$.Degradation of the quality of water in the Singrauli coalfield due to toxic pollutants, acid mine drainage and disturbance in Hydrology.The present study was carried out to determine the physicochemical characteristics of groundwater during the pre and post- monsoon seasons in the study area and compared the results with WHO drinking water quality standards ${ }^{6}$.Global Positioning System (GPS) was used to identify the sample location of groundwater around Singrauli coalfield area.

\section{Study Area}

The study area lies partly in Singrauli district of Madhya Pradesh and partly in Sonebhadra District of Uttar Pradesh ${ }^{5}$.The study area bounded by the coordinates $24^{\circ} 00^{\prime}$ to $24^{\circ} 15^{\prime} \mathrm{N}$ latitudes and $82^{\circ} 30^{\prime}$ to $82^{\circ} 45^{\prime} \mathrm{E}$ longitudes ${ }^{7}$. The climate of the study area is tropical monsoonal with extreme temperatures ranging from 47.2 to $6^{\circ} \mathrm{C}$ during summer and winter, respectively. Annual average rainfall in the study area is $1,119.65 \mathrm{~mm}$. The study area is part of the Son-Rihand basin and the major streams draining the area are Matwani, Mayar, Mehrauli, Kachan, Bijul and Baliya nala. The drainage pattern of the study area

Rasayan J. Chem., 12(2), 608-615(2019)

http://dx.doi.org/10.31788/RJC.2019.1225105

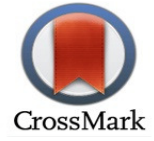


RASĀYAN J. Chem.

Vol. 12 | No. 2 |608-615 | April - June | 2019

is Dendritic drainage pattern developed which is totally controlled by topography and lithology.This coalfield stands as a high plateau over the surrounding plains covered by Talchir sediments.The Barakar sediments project over the Talchir outcrops as scarp faces. The Singrauli plateau rises to a height of over 500m above M.S.L.Location map of the study area are shown in Fig-1.

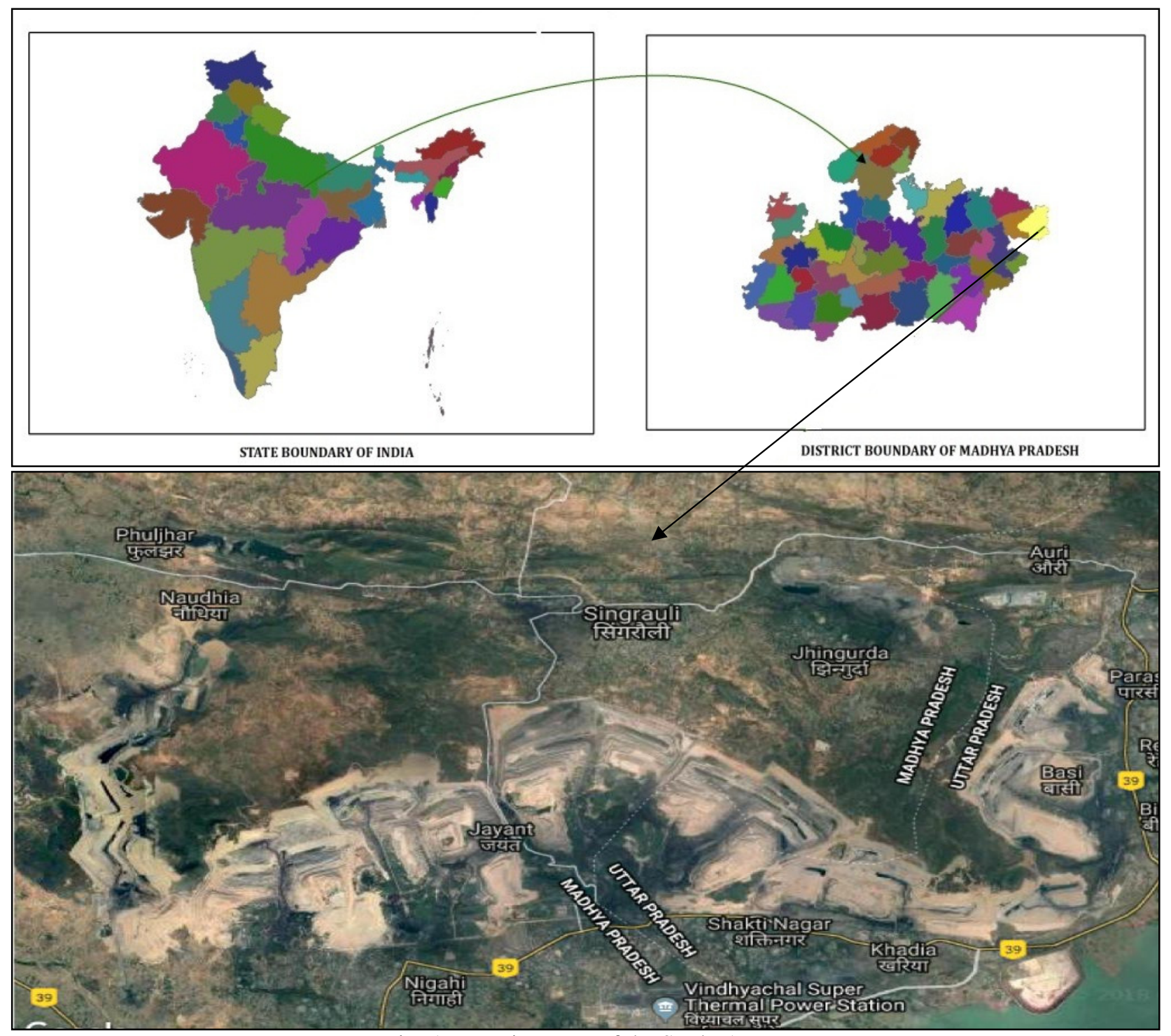

Fig.-1: Location Map of the Study Area

Table-1: Details of Sampling Locations of the Study Area

\begin{tabular}{c|c|c|c|c}
\hline S.No. & $\begin{array}{c}\text { Sample } \\
\text { Code }\end{array}$ & Type of Water & Latitude(N) & Longitude(E) \\
\hline 1. & GW1 & Hand Pump & $24^{\circ} 12^{\prime} 15^{\prime \prime}$ & $82^{\circ} 39^{\prime} 32^{\prime \prime}$ \\
\hline 2. & GW2 & Hand Pump & $24^{\circ} 11^{\prime} 25^{\prime \prime}$ & $82^{\circ} 38^{\prime} 57^{\prime \prime}$ \\
\hline 3. & GW3 & Hand Pump & $24^{\circ} 07^{\prime} 29^{\prime \prime}$ & $82^{\circ} 40^{\prime} 45^{\prime \prime}$ \\
\hline 4. & GW4 & Dug Well & $24^{\circ} 06^{\prime} 47^{\prime \prime}$ & $82^{\circ} 37^{\prime} 06^{\prime \prime}$ \\
\hline 5. & GW5 & Hand Pump & $24^{\circ} 05^{\prime} 04^{\prime \prime}$ & $82^{\circ} 39^{\prime} 29^{\prime \prime}$ \\
\hline 6. & GW6 & Hand Pump & $24^{\circ} 07^{\prime} 29^{\prime \prime}$ & $82^{\circ} 40^{\prime} 44^{\prime \prime}$ \\
\hline 7. & GW7 & Dug Well & $24^{\circ} 07^{\prime} 08^{\prime \prime}$ & $82^{\circ} 42^{\prime} 29^{\prime \prime}$ \\
\hline 8. & GW8 & Dug Well & $24^{\circ} 09^{\prime} 22^{\prime \prime}$ & $82^{\circ} 46^{\prime} 07^{\prime \prime}$ \\
\hline
\end{tabular}


RASĀYAN J. Chem.

Vol. 12 | No. 2 |608-615 | April - June | 2019

\section{Sampling Techniques}

\section{EXPERIMENTAL}

Groundwater Samples were collected in Polythene bottles of 1.0 liter. In the present investigation, groundwater samples were collected from the Dug-wells and hand pumps of Eight different stations around Singrauli coalfields region during pre-monsoon and post-monsoon seasonsin the year 2018(Fig.2).It was ensured that the concentrations of various water quality parameters do not changes in time that elapse between the drawing of samples and the analysis in the laboratory.Groundwater samples wereimmediately transferred to the laboratory for the physicochemical analysis. The various water quality parameters such as $\mathrm{pH}$, electrical conductivity, dissolved oxygen and total dissolved solids wereanalyzed at the sampling station by using the Multiparameterapparatusand other parameters like Fluoride, Chlorides, Nitrate, Sulphate, Lithium, Sodium, Potassium, Magnesium and Calcium were analyses in the laboratory.The details of sampling location along with their latitude and longitude are given in Table-1.
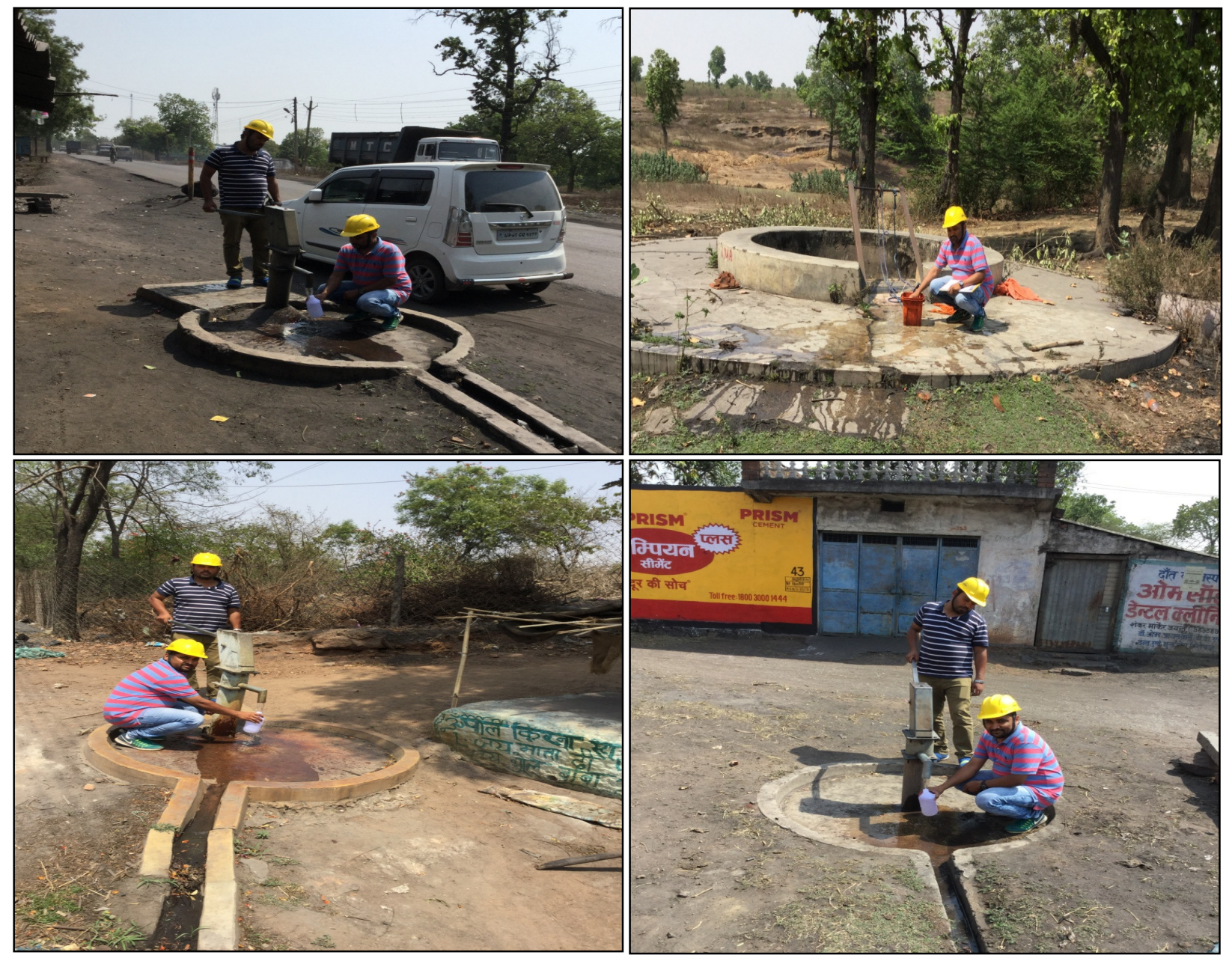

Fig.-2: Water Sampling of the Study Area

\section{RESULTS AND DISCUSSION}

The collected groundwater sample was analyzed in the laboratory for various water quality parameters viz. pH, TDS, EC, DO, Fluoride, Chlorides,Nitrate,Sulphate,Lithium,Sodium,Potassium,Magnesiumand Calcium.The physicochemical characteristics of the analyzed water sample of pre-monsoon and postmonsoon seasons have been presented in Table-2 \& Table-5.Various statistical analysis of the experimental data was performed using Microsoft Excel 2016. The statistical analysis of physico 
chemical parameters of groundwater quality of Singrauli coalfield region during the pre-monsoon and post-monsoon seasons is presented in Table-3 and Table- 6 .

\section{pH}

The $\mathrm{pH}$ value of groundwater samples varied between 7.18 to 7.98 during pre-monsoon and 6.85 to 7.34 during post-monsoon seasons. The sampling points-GW-3 showed high $\mathrm{pH}$ value in the pre-monsoon seasons.

\section{Total Dissolved Solids (TDS)}

Total dissolved solids (TDS) is the term used to describe the inorganic salts and small amounts of organic matter present in solution in water.In the present study TDS value ranged from $146 \mathrm{mg} / \mathrm{l}$ to $467 \mathrm{mg} / \mathrm{l}$ in the pre-monsoon season and $109 \mathrm{mg} / \mathrm{l}$ to $382 \mathrm{mg} / \mathrm{l}$ during post-monsoon season. The sampling pointsGW-5 showed high TDS value in both monsoons.

\section{Electrical Conductivity (EC)}

Electrical conductivity (EC) is a measure of water capacity to convey electric current ${ }^{12}$. Electrical conductivity was found to be very high and ranges from $248-933 \mu \mathrm{s} / \mathrm{cm}$ in the pre-monsoon season and $212-831 \mu \mathrm{s} / \mathrm{cm}$ during post monsoon. The sampling points-GW-4, 5,6,7,8 showed high EC value in the pre-monsoon seasons and GW-5, 6, 7, 8 during post-monsoon.

\section{Dissolved oxygen (DO)}

The concentration of Dissolved oxygen of groundwater sample ranges (4.98-5.72) $\mathrm{mg} / \mathrm{l}$ in the premonsoon season and (5.02-5.72) $\mathrm{mg} / \mathrm{l}$ during post monsoon.

\section{Fluoride $\left(\mathbf{F}^{-}\right)$}

Fluoride is a geochemical contaminant and natural sources account for most of the fluoride in surface and ground water. Its concentration is dependent on the solubility of fluoride-containing rocks. Intake of excess fluoride causes skeletal and dental fluorosis ${ }^{8}$.Fluoride content of the study area is ranged from $0.342 \mathrm{mg} / \mathrm{l}$ to $0.958 \mathrm{mg} / \mathrm{l}$ in the pre-monsoon season and $0.314 \mathrm{mg} / \mathrm{l}$ to $0.701 \mathrm{mg} / \mathrm{lduring}$ post monsoon.

\section{Chlorides ( $\left.\mathrm{Cl}^{-}\right)$}

Chloride is the most important parameter in assessing the water quality and higher concentration of chloride indicates a higher degree of organic pollution ${ }^{5}$. The concentration of Chlorides ion of groundwater sample ranges from (10.312-192.433) $\mathrm{mg} / \mathrm{l}$ in the pre-monsoon season and (08.241-161.712) $\mathrm{mg} / \mathrm{l}$ during post monsoon. The sampling points-GW-5 showed high Chlorides value in both monsoons.

\section{Nitrate $\left(\mathrm{NO}_{3}^{-}\right)$}

The nitrate content of the groundwater samples ranges from ( 0.773 to 39.560$) \mathrm{mg} / \mathrm{lin}$ the pre-monsoon season and (0.697to 32.743) $\mathrm{mg} / \mathrm{l}$ during post monsoon.

\section{Sulfate $\left(\mathrm{SO}_{4}^{-2}\right)$}

The sulfate concentration of the groundwater samples varied between (5.947 to 95.246$) \mathrm{mg} / \mathrm{l}$ in the premonsoon season and (5.242to 79.479) $\mathrm{mg} / \mathrm{lduring}$ post-monsoon of the study area.

\section{Lithium $\left(\mathbf{L i}^{+}\right)$}

The Lithium concentration of the groundwater samples varied between $(0.069$ to 0.086$) \mathrm{mg} / \mathrm{l}$ in the premonsoon season and (0.069 to 0.084$) \mathrm{mg} / \mathrm{lduring}$ post monsoon.

\section{Sodium $\left(\mathrm{Na}^{+}\right)$}

The concentration of Sodium ion of groundwater sample ranges (8.754-117.452) $\mathrm{mg} / \mathrm{lin}$ the pre-monsoon season and (6.283 to 98.197$) \mathrm{mg} / \mathrm{lduring}$ post monsoon. The permissible limit of magnesium is $70 \mathrm{mg} / \mathrm{l}$.

\section{Potassium $\left(\mathbf{K}^{+}\right)$}

Potassium content in the groundwater samples of the study area varied from (0.316to 5.294) $\mathrm{mg} / \mathrm{l} \mathrm{in}$ the pre-monsoon season and (0.259 to 4.178$) \mathrm{mg} / \mathrm{lduring}$ post monsoon. Increase concentration of sodium and potassium may be seen in the groundwater of the mining area in comparison to the non-mining area. 


\section{RASĀYAN J. Chem.}

Vol. 12 | No. 2 |608-615 | April - June | 2019

\section{Magnesium $\left(\mathrm{Mg}^{+2}\right)$}

Potassium content in the groundwater samples of the study area varied from (0.316to 5.294) $\mathrm{mg} / \mathrm{l}$ in the pre-monsoon season and (0.259 to 4.178$) \mathrm{mg} / \mathrm{lduring}$ post-monsoon. Geochemistry of magnesium is quite similar to that of calcium.

\section{Calcium $\left(\mathbf{C a}^{+2}\right)$}

The concentration of calcium ion of groundwater sample of the study area varied from (18.481$91.855) \mathrm{mg} / \mathrm{lin}$ the pre-monsoon season and (12.241-61.415) $\mathrm{mg} / \mathrm{l}$ during post-monsoon. The acceptable limit of calcium is (75-200) $\mathrm{mg} / \mathrm{l}$, as per (WHO) recommendations. The sampling points-GW-6 showed high Calcium value in both monsoons.

Table-2: Physico-Chemical Parameters of Water Samples of Singrauli Coalfield During Pre-monsoon Season (2018).

\begin{tabular}{|c|c|c|c|c|c|c|c|c|}
\hline$\stackrel{\text { Sample Code }}{\longrightarrow}$ & GW- 1 & GW-2 & GW-3 & GW-4 & GW-5 & GW-6 & GW-7 & GW-8 \\
\hline $\mathrm{pH}$ & 7.18 & 7.82 & 7.98 & 7.52 & 7.64 & 7.46 & 7.68 & 7.68 \\
\hline TDS & 282 & 146 & 162 & 260 & 467 & 312 & 228 & 272 \\
\hline EC & 456 & 248 & 272 & 319 & 933 & 619 & 453 & 523 \\
\hline DO & 5.58 & 4.98 & 5.72 & 5.42 & 5.46 & 5.48 & 5.12 & 5.38 \\
\hline Fluoride & 0.342 & 0.482 & 0.958 & 0.546 & 0.520 & 0.621 & 0.907 & 0.552 \\
\hline Chlorides & 75.646 & 24.51 & 15.825 & 28.296 & 192.433 & 29.891 & 19.842 & 10.312 \\
\hline Nitrate & 5.926 & 6.392 & 10.180 & 39.560 & 14.426 & 24.716 & 0.773 & 0.902 \\
\hline Sulphate & 35.725 & 9.546 & 26.925 & 15.247 & 95.246 & 5.947 & 27.523 & 11.122 \\
\hline Lithium & 0.070 & 0.080 & 0.070 & 0.084 & 0.086 & 0.079 & 0.073 & 0.069 \\
\hline Sodium & 64.35 & 23.158 & 19.697 & 18.109 & 117.452 & 19.357 & 24.432 & 8.754 \\
\hline Potassium & 5.294 & 1.784 & 0.316 & 4.182 & 1.869 & 2.107 & 1.113 & 2.476 \\
\hline Magnesium & 21.185 & 9.468 & 4.581 & 17.686 & 19.825 & 18.592 & 11.512 & 5.876 \\
\hline Calcium & 18.481 & 15.828 & 58.925 & 29.820 & 91.855 & 72.315 & 59.125 & 18.674 \\
\hline
\end{tabular}

All parameters are given in $\mathrm{mg} / \mathrm{l}$, excluding $\mathrm{pH}$ and Electrical conductivity $(\mu \mathrm{S} / \mathrm{cm})$.

Table-3: Summary of Statistics of Groundwater parameter during pre-monsoon season.

\begin{tabular}{c|c|c|c|c|c|c}
\hline Parameter & Min & Max & Mean & Median & S.D & $\begin{array}{c}\text { Permissible limit by } \\
\text { WHO and BIS }\end{array}$ \\
\hline $\mathrm{pH}$ & 7.18 & 7.98 & 7.62 & 7.66 & 0.2409 & $6.5-8.5$ \\
\hline TDS & 146 & 467 & 266.125 & 266 & 99.6457 & 500 \\
\hline EC & 248 & 933 & 477.875 & 454.5 & 223.8165 & 300 \\
\hline DO & 4.98 & 5.72 & 5.3925 & 5.44 & 0.2390 & $>5$ \\
\hline Fluoride & 0.342 & 0.958 & 0.616 & 0.549 & 0.2114 & 1.5 \\
\hline Chlorides & 10.312 & 192.433 & 49.594 & 26.403 & 61.0869 & 250 \\
\hline Nitrate & 0.773 & 39.560 & 12.859 & 8.286 & 13.3207 & 45 \\
\hline Sulphate & 5.947 & 95.246 & 28.410 & 21.086 & 28.92386 & 150 \\
\hline Lithium & 0.069 & 0.086 & 0.0763 & 0.076 & 0.06739 & ---- \\
\hline Sodium & 8.754 & 117.452 & 36.913 & 21.427 & 36.51892 & 200 \\
\hline Potassium & 0.316 & 5.294 & 2.392 & 1.988 & 1.616999 & 15 \\
\hline Magnesium & 4.581 & 21.185 & 13.590 & 14.599 & 6.550172 & 30 \\
\hline Calcium & 15.828 & 91.855 & 45.627 & 44.372 & 28.80853 & 75 \\
\hline
\end{tabular}

Note: Min-Minimum, Max-Maximum, SD-Standard deviation

The correlation coefficients ( $r$ ) among the various groundwater quality parameters of Singrauli coalfields for the pre-monsoon and post-monsoon seasons have been calculated and the numerical values are tabulated as shown in Table- 4 and Table- 7. 
RASĀYAN J. Chem.

Vol. 12 | No. 2 |608-615 | April - June | 2019

Table-4: Correlation Matrix of Groundwater Quality Parameters (Pre-Monsoon Season).

\begin{tabular}{|c|c|c|c|c|c|c|c|c|c|c|c|c|c|}
\hline & $\mathrm{pH}$ & TDS & EC & D0 & $\mathrm{F}$ & $\mathrm{Cl}$ & $\mathrm{NO}_{3}^{-}$ & $\mathrm{SO}_{4}^{-2}$ & $\mathrm{Li}^{+}$ & $\mathrm{Na}^{+}$ & $\mathrm{K}^{+}$ & $\mathrm{Mg}^{+2}$ & $\mathrm{Ca}^{+2}$ \\
\hline$\overline{\mathrm{pH}}$ & 1 & & & & & & & & & & & & \\
\hline TDS & -0.435 & 1 & & & & & & & & & & & \\
\hline EC & -0.283 & 0.953 & 1 & & & & & & & & & & \\
\hline DO & -0.197 & 0.277 & 0.182 & 1 & & & & & & & & & \\
\hline$F^{*}$ & 0.658 & -0.366 & -0.228 & 0.083 & 1 & & & & & & & & \\
\hline $\mathrm{Cl}^{-}$ & -0.239 & 0.839 & 0.802 & 0.197 & -0.374 & 1 & & & & & & & \\
\hline $\mathrm{NO}_{3}^{-}$ & -0.231 & 0.219 & 0.005 & 0.261 & -0.145 & 0.057 & 1 & & & & & & \\
\hline $\mathrm{SO}_{4}^{-2}$ & -0.049 & 0.741 & 0.730 & 0.234 & -0.111 & 0.945 & -0.082 & 1 & & & & & \\
\hline $\mathrm{Li}^{+}$ & -0.035 & 0.472 & 0.370 & -0.237 & -0.288 & 0.524 & 0.663 & 0.373 & 1 & & & & \\
\hline $\mathrm{Na}^{+}$ & -0.279 & 0.773 & 0.740 & 0.202 & -0.368 & 0.984 & -0.045 & 0.948 & 0.418 & 1 & & & \\
\hline $\mathbf{K}^{+}$ & -0.866 & 0.226 & -0.009 & 0.167 & -0.785 & 0.128 & 0.315 & -0.051 & 0.054 & 0.161 & 1 & & \\
\hline $\mathrm{Mg}^{+2}$ & -0.822 & 0.666 & 0.510 & 0.165 & -0.576 & 0.598 & 0.481 & 0.401 & 0.525 & 0.598 & 0.646 & 1 & \\
\hline $\mathrm{Ca}^{+2}$ & 0.169 & 0.582 & 0.675 & 0.275 & 0.432 & 0.541 & 0.175 & 0.599 & 0.389 & 0.486 & -0.515 & 0.253 & 1 \\
\hline
\end{tabular}

Table-5: Physico-Chemical Parameters of Water Samples of Singrauli Coalfield During Post-monsoon Season (2018).

\begin{tabular}{|c|c|c|c|c|c|c|c|c|}
\hline$\stackrel{\text { Sample Code }}{\stackrel{\text { Parameter }}{\longrightarrow}}$ & GW- 1 & GW-2 & GW-3 & GW-4 & GW-5 & GW-6 & GW-7 & GW-8 \\
\hline $\mathrm{pH}$ & 7.09 & 6.85 & 7.12 & 7.25 & 7.21 & 7.12 & 7.24 & 7.34 \\
\hline TDS & 256 & 109 & 128 & 183 & 382 & 274 & 191 & 278 \\
\hline $\mathrm{EC}$ & 432 & 212 & 198 & 285 & 831 & 549 & 325 & 417 \\
\hline DO & 5.12 & 5.02 & 5.98 & 5.72 & 5.61 & 5.48 & 5.04 & 5.42 \\
\hline Fluoride & 0.314 & 0.389 & 0.647 & 0.385 & 0.471 & 0.529 & 0.701 & 0.459 \\
\hline Chlorides & 69.258 & 21.32 & 11.142 & 22.729 & 161.712 & 21.227 & 16.142 & 08.241 \\
\hline Nitrate & 4.821 & 4.852 & 7.971 & 32.743 & 11.874 & 19.617 & 0.697 & 0.713 \\
\hline Sulphate & 31.358 & 7.297 & 21.417 & 12.925 & 79.479 & 5.242 & 23.478 & 10.254 \\
\hline Lithium & 0.069 & 0.070 & 0.070 & 0.070 & 0.084 & 0.070 & 0.070 & 0.070 \\
\hline Sodium & 56.21 & 19.673 & 13.549 & 13.824 & 98.197 & 13.719 & 19.852 & 6.283 \\
\hline Potassium & 4.178 & 1.249 & 0.259 & 3.271 & 1.247 & 1.847 & 0.986 & 1.879 \\
\hline Magnesium & 18.451 & 7.917 & 3.463 & 11.493 & 13.549 & 13.253 & 09.741 & 3.651 \\
\hline Calcium & 16.32 & 12.241 & 43.571 & 22.467 & 81.174 & 61.415 & 48.967 & 16.419 \\
\hline
\end{tabular}

All parameters are given in $\mathrm{mg} / \mathrm{l}$, excluding $\mathrm{pH}$ and Electrical conductivity $(\mu \mathrm{S} / \mathrm{cm})$.

Table-6: Summary of Statistics of Groundwater Parameter during Post-monsoon Season.

\begin{tabular}{c|c|c|c|c|c|c}
\hline Parameter & Min & Max & Mean & Median & S.D & $\begin{array}{c}\text { Permissible limit by } \\
\text { WHO and BIS }\end{array}$ \\
\hline $\mathrm{pH}$ & 6.85 & 7.34 & 7.152 & 7.165 & 0.1479 & $6.5-8.5$ \\
\hline TDS & 109 & 382 & 225.125 & 223.5 & 89.9244 & 500 \\
\hline EC & 212 & 831 & 406.125 & 371 & 208.3859 & 300 \\
\hline DO & 5.02 & 5.72 & 5.423 & 5.45 & 0.3459 & $>5$ \\
\hline Fluoride & 0.314 & 0.701 & 0.4868 & 0.465 & 0.1331 & 1.5 \\
\hline Chlorides & 08.241 & 161.712 & 41.471 & 21.273 & 52.1848 & 250 \\
\hline Nitrate & 0.697 & 32.743 & 10.411 & 6.4115 & 10.9683 & 45 \\
\hline Sulphate & 5.242 & 79.479 & 23.931 & 17.171 & 24.14666 & 150 \\
\hline Lithium & 0.069 & 0.084 & 0.071 & 0.070 & 0.0050 & ---- \\
\hline Sodium & 6.283 & 98.197 & 30.163 & 16.748 & 31.4121 & 200 \\
\hline
\end{tabular}


RASĀYAN J. Chem.

Vol. 12 | No. 2 |608-615 | April - June | 2019

\begin{tabular}{c|c|c|c|c|c|c}
\hline Potassium & 0.259 & 4.178 & 1.8645 & 1.548 & 1.2784 & 15 \\
\hline Magnesium & 3.463 & 18.451 & 10.189 & 10.617 & 5.1267 & 30 \\
\hline Calcium & 12.241 & 81.174 & 37.821 & 33.019 & 25.0823 & 75 \\
\hline
\end{tabular}

Note: Min-Minimum, Max-Maximum, SD-Standard deviation

Table-7: Correlation Matrix of Groundwater Quality Parameters (Post-monsoon Season).

\begin{tabular}{|c|c|c|c|c|c|c|c|c|c|c|c|c|c|}
\hline & $\mathrm{pH}$ & TDS & $\mathrm{EC}$ & D0 & $\mathrm{F}$ & $\mathrm{Cl}^{-}$ & $\mathrm{NO}_{3}^{-}$ & $\mathrm{SO}_{4}^{-2}$ & $\mathrm{Li}^{+}$ & $\mathrm{Na}^{+}$ & $\mathrm{K}^{+}$ & $\mathrm{Mg}^{+2}$ & $\mathrm{Ca}^{+2}$ \\
\hline $\mathrm{pH}$ & 1 & & & & & & & & & & & & \\
\hline TDS & 0.501 & 1 & & & & & & & & & & & \\
\hline EC & 0.310 & 0.958 & 1 & & & & & & & & & & \\
\hline DO & 0.353 & 0.073 & 0.074 & 1 & & & & & & & & & \\
\hline $\mathrm{F}^{-}$ & 0.265 & -0.172 & -0.128 & 0.212 & 1 & & & & & & & & \\
\hline $\mathrm{Cl}^{-}$ & 0.049 & 0.728 & 0.829 & 0.066 & -0.268 & 1 & & & & & & & \\
\hline $\mathrm{NO}_{3}^{-}$ & 0.124 & 0.039 & 0.085 & 0.518 & -0.254 & 0.042 & 1 & & & & & & \\
\hline $\mathrm{SO}_{4}^{-2}$ & 0.191 & 0.655 & 0.741 & 0.159 & -0.014 & 0.946 & -0.077 & 1 & & & & & \\
\hline $\mathrm{Li}^{+}$ & 0.167 & 0.686 & 0.810 & 0.240 & -0.011 & 0.904 & 0.068 & 0.909 & 1 & & & & \\
\hline $\mathrm{Na}^{+}$ & -0.014 & 0.672 & 0.770 & -0.026 & -0.266 & 0.986 & -0.055 & 0.943 & 0.841 & 1 & & & \\
\hline $\mathbf{K}^{+}$ & 0.092 & 0.214 & 0.080 & -0.229 & -0.772 & 0.100 & 0.338 & -0.082 & -0.244 & 0.133 & 1 & & \\
\hline $\mathrm{Mg}^{+2}$ & -0.123 & 0.454 & 0.498 & -0.318 & -0.472 & 0.548 & 0.287 & 0.370 & 0.216 & 0.593 & 0.683 & 1 & \\
\hline $\mathrm{Ca}^{+2}$ & 0.234 & 0.560 & 0.703 & 0.341 & 0.513 & 0.567 & 0.148 & 0.631 & 0.714 & 0.512 & -0.455 & 0.194 & \\
\hline
\end{tabular}

Test of Significance of the Observed Correlation Coefficient

The correlation coefficient study is very useful to determine a predictable relationship which can be exploited in practice. It is used for the measurement of the strength and statistical significance of the relation between two or more water quality parameters. Hence, it is a helpful tool for the promotion of research activities ${ }^{9-10}$.

\section{In Pre-monsoon}

In the period of Pre-monsoon season, out of 91 correlation coefficients, 25 negative and 66 positive correlation coefficients. InTable-4, the highly positive correlation is observed between EC and TDS (0.953), $\mathrm{Na}^{+}$and $\mathrm{SO}_{4}^{-2}(0.948), \mathrm{SO}_{4}{ }^{-2}$ and $\mathrm{Cl}^{-}(0.945)$. where highly negative correlation is observed between $\mathrm{K}^{+}$and $\mathrm{pH}(-0.866), \mathrm{Mg}^{+2}$ and $\mathrm{pH}(-0.822), \mathrm{K}^{+}$and $\mathrm{F}^{-}(-0.785)$. Very poor positive correlation was observed between $\mathrm{K}^{+}$and $\mathrm{Li}^{+}(0.054), \mathrm{F}^{-}$and $\mathrm{DO}(0.083), \mathrm{K}^{+}$and $\mathrm{Cl}^{-}(0.128), \mathrm{Mg}^{+2}$ and $\mathrm{DO}(0.165), \mathrm{K}^{+}$and $\mathrm{DO}(0.167), \mathrm{Ca}^{+2}$ and $\mathrm{pH}(0.169), \mathrm{Ca}^{+2}$ and $\mathrm{NO}_{3}^{-}(0.175), \mathrm{DO}$ and $\mathrm{EC}(0.182), \mathrm{Cl}^{-}$and DO (0.197).while, there is almost no correlation was observed between $\mathrm{NO}_{3}{ }^{-}$and $\mathrm{EC}(0.005)$.

\section{In Post-monsoon}

In the period of Post-monsoon season, out of 91 correlation coefficients, 19 negative and 72 positive correlation coefficients. In Table-7, the highly positive correlation is observed between $\mathrm{Na}^{+}$and $\mathrm{Cl}^{-}$ (0.986), EC and TDS (0.958), $\mathrm{SO}_{4}^{-2}$ and $\mathrm{Cl}^{-}(0.946), \mathrm{Na}^{+}$and $\mathrm{SO}_{4}^{-2}(0.943), \mathrm{Li}^{+}$and $\mathrm{SO}_{4}^{-2}(0.909), \mathrm{Li}^{+}$and $\mathrm{Cl}^{-}(0.904)$. where highly negative correlation is observed between $\mathrm{K}^{+}$and $\mathrm{F}^{-}(-0.772), \mathrm{Mg}^{+2}$ and $\mathrm{F}^{-}(-$ $0.472)$. Very poor positive correlation was observed betweenNO ${ }_{3}^{-}$and TDS (0.039), $\mathrm{NO}_{3}{ }^{-}$and $\mathrm{Cl}^{-}(0.042)$, $\mathrm{Li}^{+}$and $\mathrm{NO}_{3}{ }^{-}(0.068), \mathrm{DO}$ and TDS (0.073), DO and EC (0.074), $\mathrm{K}^{+}$and $\mathrm{EC}(0.080), \mathrm{NO}_{3}{ }^{-}$and $\mathrm{EC}(0.085)$, $\mathrm{K}^{+}$and $\mathrm{pH}(0.092)$,While, there is almost no correlation was observed between $\mathrm{Li}^{+}$and $\mathrm{F}^{-}(-0.011)$.

\section{CONCLUSION}

In the present study,the ground water samples taken from eight villages present in and around Singrauli coalfield area were analyzed.The correlation of 13 physicochemical parameters of groundwater of the study area revealed that all the parameter were more or less correlated with one another. The groundwater 


\section{RASĀYAN J. Chem.}

Vol. 12 | No. 2 |608-615 | April - June | 2019

of the study area is alkaline in nature.EC found above maximum permissible limit prescribed by BIS in the pre-monsoon $(933 \mu \mathrm{S} / \mathrm{cm})$ and post-monsoon $(831 \mu \mathrm{S} / \mathrm{cm})$.From correlation analysis it was observed that very strong correlation exit between EC and TDS (0.953), $\mathrm{Na}^{+}$and $\mathrm{SO}_{4}^{-2}(0.948), \mathrm{SO}_{4}^{-2}$ and $\mathrm{Cl}^{-}$ (0.945) during pre-monsoon season and $\mathrm{Na}^{+}$and $\mathrm{Cl}^{-}(0.986)$, EC and TDS (0.958), $\mathrm{SO}_{4}^{-2}$ and $\mathrm{Cl}^{-}$ (0.946), $\mathrm{Na}^{+}$and $\mathrm{SO}_{4}^{-2}$ (0.943), $\mathrm{Li}^{+}$and $\mathrm{SO}_{4}^{-2}$ (0.909), $\mathrm{Li}^{+}$and $\mathrm{Cl}^{-}(0.904)$ during post-monsoon. The analysis shows that the groundwater of the study area needs some treatment before its consumption.

\section{ACKNOWLEDGMENT}

The authors are especially thankful to the Department of Mining Engineering, Indian Institute of Technology, Banaras Hindu University, Varanasi for providing the technical support during the whole Research period.

\section{REFERENCES}

1. R. Kavitha and K. Elangovan, International Journal of Environmental Sciences, 1(2), 145(2010).

2. S. Packialakshmi, N. K. Ambujam, P. Nelliyat, Journal of Environment, Development and Sustainability, 13(2), 423(2011)

3. J. Abdul Bari, G. Vennila and T. M. Shanmugaraja, Rasayan J. Chem., 8(2), 198(2015).

4. Prasoon Kumar Singh, Ashwani Kumar Tiwari and Mukesh Kumar Mahato, International Journal of ChemTech Research,5(5), 2351(2013).

5. A. K. Sonkar and A. Jamal, Rasayan J. Chem., 11(3), 1270(2018), DOI: 10.31788/RJC.2018.1134026

6. WHO (World Health Organisation), International Standards for Drinking Water, Geneva, WHO, (2007).

7. Ramita Varshney and Aarif Jamal, Rasayan J. Chem., 11(3), 1177(2018), DOI: 10.31788/RJC.2018.1134023

8. Bharat Singh Meena and Nandan Bhargava, Rasayan J. Chem., 5(4), 438(2012)

9. R. R. Sangpal, U. D. Kulkarni, Y. M. Nandurkar, Aparn J. of Agricultural and Biol. Sci., 6(3),34(2011).

10. M. R. Murthuzasab, M. Rajashekhar, K. Vijaykumar, N. S. Haliked, Inter. J. of Systems Biol., 2(2), 16(2010).

11. G. H. Mushekar, Res. J. Chem. Sci., 1 (4), 117(2011).

12. S. Dahiya and A. Kaur,J. Environ. Poll., 6(4), 281(1999).

[RJC-5105/2018] 